\title{
Hubungan Pengetahuan dan Status Pekerjaan Ibu dengan Pemberian MP- ASI pada Bayi Usia 7-12 Bulan di Wilayah Kerja Puskesmas Batoh Banda Aceh Tahun 2018
}

\author{
Relationship between Knowledge and Employment Status of Mothers with \\ Giving Breast Milk in Babies 7-12 Months in the Batoh Banda Aceh Health \\ Center Working Area in 2018 \\ Chairanisa Anwar* ${ }^{1}$, Zelia Ulfa ${ }^{2}$ \\ ${ }^{1}$ Universitas Ubudiyah Indonesia, Jalan Alue Naga Desa Tibang, Banda Aceh, Indonesia \\ ${ }^{2}$ D-IV Kebidanan Poltekkes Kemenkes Aceh \\ *Korespondensi Penulis: chaira.anwar@uui.ac.id
}

\begin{abstract}
Abstrak
Turut sertanya ibu dalam mencari nafkah akan menimbulkan masalah, yaitu pembagian waktu terutama dalam hal waktu untuk bekerja di luar rumah dengan waktu untuk mengelola rumah tangga serta mengasuh anak. Keterbatasan waktu ibu dalam mengasuh anak dan menyediakan makanan akan berpengaruh terhadap pola makan anak (bayi) dan konsumsi gizi anak, karena pada usia anak-anak ini merupakan usia yang membutuhkan konsumsi pangan yang ideal untuk membantu kecerdasan. Tujuan penelitian ini untuk mengatahui hubungan antara pengetahuan, status pekerjaan ibu dengan pemberian MP-ASI. Hasil penelitian ini menunjukkan ada hubungan yang signifikan antara Pengetahuan dengan pemberian MP-ASI dengan pvalue $=0.023$, dan terdapat hubungan antara status pekerjaan dengan pemberian MPASI dengan pvalue $=0,011$.
\end{abstract}

Kata kunci: pengetahuan, status pekerjaan, MP-ASI

\begin{abstract}
Dietary supplements or food companion ASI (MP-ASI) is given to the baby food in addition to breast milk to meet the nutritional. MP-ASI at the age of 6-24 months and the transition from breast milk to feed a family meal, and the introduction of the MP-ASI grant this should be done gradually, either in the form or amount. It is intended to acquire the ability to digest baby receives the MP-ASI. State of malnutrition in infants and children caused by the MP-ASI habit of giving inaccurate and ignorance and the mother of mamfaat MP-ASI means giving up the right to influence the provision of MP-ASI.To analyze the relationship between knowledge, mother's work status by giving the MP-ASI.Resultsthe results showed no significant relationship between knowledge by giving the MP-ASI with pvalue $=0.023$, and there is a relationship between the employment status of the grant of the MP-ASI with pvalue $=0.011$.
\end{abstract}

Keywords: knowledge, job status, MP-ASI 


\section{PENDAHULUAN}

Untuk mencapai tumbuh kembang optimal, di dalam Global Strategy Infant and You child Feeding, WHO/UNICEF merekomendasikan empat hal penting yang harus dilakukan yaitu : pertama memberikan air susu ibu kepada bayi segera dalam waktu 30 menit setelah bayi lahir, kedua memberikan hanya air susu ibu (ASI) saja atau pemberian ASI secara eksklusif sejak lahir sampai bayi berusia 6 bulan, ketiga memberikan makanan pendamping air susu ibu (MP-ASI) sejak bayi berusia 6 bulan sampai 24 bulan, dan keempat meneruskan pemberian ASI sampai anak berusia 24 bulan atau lebih. Rekomendasi tersebut menekankan, secara social budaya MP-ASI hendaknya dibuat dari bahan pangan yang murah dan mudah diperoleh di daerah setempat (indigenous food) (WHO, 2003).

Mengasuh dan membesarkan seorang bayi merupakan suatu petualang yang berlangsung terus menerus mulai dari pemberian ASI sampai untuk mengenal makanan bayi. Turut sertanya ibu dalam mencari nafkah akan meningkatkan daya beli keluarga, akan tetapi juga menimbulkan masalah, yaitu pembagian waktu terutama dalam hal waktu untuk bekerja di luar rumah dengan waktu untuk mengelola rumah tangga serta mengasuh anak. Peran ganda ibu ini menuntut di satu pihak perlu curahan waktu penuh untuk mengasuh anak, bersamaan dengan itu perlu sisipan waktu untuk bekerja di luar rumah. Salah satu peluang untuk mengatasinya adalah anak diasuh oleh pembantu, keluarga atau family yang ada di rumah. Keterbatasan waktu ibu dalam mengasuh anak dan menyediakan makanan akan berpengaruh terhadap pola makan anak (bayi) dan konsumsi gizi anak, karena pada usia anakanak ini merupakan usia yang membutuhkan konsumsi pangan yang ideal untuk membantu kecerdasan. Berdasarkan data yang diperoleh dari BPS Kota Banda Aceh Tahun 2012 bahwa $67 \%$ ibu rumah tangga di Kecamatan Batoh Banda Aceh.

Makanan yang diberikan untuk pertama kali akan berpengaruh sangat besar dalam kesehatan bayi kemudian hal yang bermamfaat bagi pertumbuhannya (Kalnins, 2003), Agar pemberian makanan pendamping ASI berjalan baik maka diperlukan pengetahuan dan perilaku yang baik pula mengenai makanan pendamping ASI. Salah satu faktor intern yang mempengaruhi terbentuknya perilaku manusia adalah pengetahuan (Notoatmodjo, 2003).

Pengetahuan pada dasarnya adalah hasil dari tahu yang terjadi setelah orang melakukan pengindraan terhadap suatu objek tertentu melalui panca indra manusia, yakni indra penglihatan, pendengaran, penciuman, rasa dan raba. Sebagian besar pengetahuan diperoleh melalui mata dan telinga. Perilaku kesehatan dipengaruhi pula oleh pengetahuan sebagai 
faktor predispoisi. Jika pengetahuan tentang makanan pendamping ASI baik diharapkan pula pada akhirnya perilaku terhadap makanan pendamping ASI juga baik (Notoadmodjo, 2007).

Penelitian yang dilakukan oleh Mintardja (2009) menyebutkan bahwa faktor-faktor yang mempengaruhi pemberian MP-ASI oleh ibu kepada bayinya adalah pengetahuan, pendidikan, sosial budaya atau tradisi, ekonomi keluarga, sikap, motivasi, dan dukungan suami.

Pemberian makanan pendamping ASI meliputi terutama mengenai kapan makanan pendamping ASI harus diberikan, jenis bentuk dan jumlahnya (Krisnatuti, 2000). Cara pemberian pertama kali berbentuk cair menjadi lebih kental secara bertahap (Octopus, 2006). Jadi makan pendamping ASI yang cukup dalam hal kualitas ataupun kuantitas, penting untuk perubahan fisik dan perkembangan anak (Graimes, 2008).

Makanan pendamping ASI seharusnya diberikan setelah bayi berumur 6 bulan karena dapat memberikan manfaat yang besar pada bayi (Kodrat, 2010). Peran serta ibu yang memiliki bayi memegang peranan penting untuk mencegah pemberian makanan pendamping ASI yang tidak tepat. Selain itu pihak Kader di Posyandu juga perlu menggalakkan pendidikan kesehatan pada ibu agar makanan pendamping ASI dapat diberikan secara tepat. Pemberian makanan pendamping ASI harus tepat waktu karena jika diberikan terlalu dini (kurang dari 6 bulan) akan menurunkan konsumsi ASI dan bayi mengalami gangguan pencernaan atau bisa diare. Faktor-faktor yang mempengaruhi pemberian makanan tambahan pada bayi usia kurang dari enam bulan adalah faktor kesehatan bayi, faktor kesehatan ibu, faktor iklan, factor pengetahuan ibu, faktor pekerjaan ibu, faktor petugas kesehatan, faktor budaya dan faktor sosial ekonomi. Dalam hal ini perilaku ibu memegang peranan penting untuk mencegah pemberian makanan pendamping ASI yang tidak tepat sehingga akan mengurangi resiko bayi mengalami gangguan pencernaan dan dapat memiliki daya tahan tubuh yang lebih kuat.

Menurut Depkes RI (2004) menyatakan bahwa makanan tambahan atau makanan pendamping ASI (MP-ASI) adalah makanan yang diberikan pada bayi di samping ASI untuk memenuhi gizinya. MP-ASI diberikan pada usia 6-24 bulan dan merupakan makanan peralihan dari ASI ke makanan keluarga, pengenalan dan pemberian MP-ASI ini harus dilakukan secara bertahap baik dalam bentuk maupun jumlah. Hal ini dimaksudkan untuk memperoleh kemampuan mencerna bayi dalam menerima MP-ASI. Tujuan pemberian makanan tambahan pada bayi diantaranya untuk melengkapi zat-zat gizi yang kurang karena 
kebutuhan zat gizi akan semakin meningkat sejalan dengan bertambahnya usia bayi, mengembangkan kemampuan bayi untuk menerima bermacam-macam makanan dengan berbagai bentuk, tekstur dan rasa. Serta mengembangkan kemampuan bayi untuk menelan, mengunyah bayi (Depkes RI, 1992). Judarwanto, 2004 menyatakan bahan makanan tambahan pada bayi dibedakan atas 2 golongan yaitu hewani dan nabati. Golangan hewani terdiri dari ikan, telur, daging. Golongan nabati terdiri dari buah-buahan, sayur-sayuran, dan padi-padian (Baso, 2007). Makanan tambahan yang baik adalah makanan yang mengandung sejumlah kalori atau energi (karbohidrat, protein, dan lemak), vitamin, serat, untuk pertumbuhan dan energi bayi, disukai bayi, mudah disiapkan dan harga terjangkau.

Penelitian di Kecamatan Medan Marelan Tahun 2004, diperoleh pola pemberian MPASI pada kategori tidak baik sebanyak 78 orang dimana 46 orang (59\%) tumbuh kembangnya normal dan 32 (42\%) tumbuh kembangnya terganggu. Berdasarkan hasil penelitian disarankan kepada petugas kesehatan untuk lebih meningktakan penyuluhan kepada ibu-ibu yang mempunyai bayi dan anak meneganai pola pemberian MP-ASI dan pentingnya pemantauan tumbuh kembang anak (Sulastri, 2004).

Aceh merupakan salah satu provinsi yang paling besar prevalensi pendek di atas angka nosional, dengan urutan ketiga terbesar prevalensi stunting yaitu sebesar 44,6\%, untuk wilayah Kota Banda Aceh prevalensinya adalah sebesar 38,8\%. Hal ini disebabkan oleh banyak faktor, diantaranya yaitu pemberian ASI Non Eklusif, Imunisasi yang tidak lengkap, dan Pemberian MP-ASI yang kurang baik, dll (Rosi, 2010).

Beberapa penelitian menyatakan bahwa keadaan kurang gizi pada bayi dan anak disebabkan karena kebiasaan pemberian MP-ASI yang tidak tepat dan ketidaktahuan ibu tentang maamfaat dan cara pemberian MP-ASI yang benar sehingga berpengaruh terhadap pemeberian MP-ASI. Yang dimaksud dengan pengetahuan ibu tentang makanan pendamping ASI adalah hasil tahu karena faktor pengindraan terhadap suatu obyek tertentu tentang bahan makanan yang diperlukan dalam satu hari yang beraneka ragam dan mengandung zat tenaga, zat pembangun dan zat pengatur yang dibutuhkan oleh tubuh bayi khusunya usia 6-12 bulan (Depkes, RI, 2006).

Akibat rendahnya sanitasi dan hygiene MP-ASI memungkinkan terjadinya kontaminasi oleh mikroba, hingga meningkatkan resiko dan infeksi lain pada bayi, hasil penelitian widodo (2006) bahwa masyarakat pedesaan di Indonesia jenis MP-ASI pada umumnya sudah diberikan kepada bayi sebelum usia 4 bulan yaitu pisang $(57,3 \%)$ dan rata-rata berat badan 
bayi yang mendapat ASI eksklusif lebih besar dari pada kelompok bayi yang diberikan MPASI (Litbangkes, 2007).

Pada dasarnya banyak ibu yang memberikan Pengganti ASI sebelum bayi berusia 6 bulan, dan penyebabnya sangat beragam, beberapa ibu kebanyakan sibuk bekerja dan sebagian masih belum terlalu memahami seperti apa ASI eksklusif itu sendiri sehingga mereka tidak memberikan ASI eksklusif. Selain itu peranan petugas kesehatan, khususnya bidan dapat mendukung upaya pemberian ASI eksklusif kepada bayi (Faizatun, 2012).

Laporan pencapaian indicator kinerja pembinaan gizi masyarakat tingkat kota Banda Aceh Tahun 2011 mengatakan, dari jumlah bayi usia 6-12 bulan yaitu 2.470 orang tercatat 100 orang diantaranya berstatus gizi buruk atau 4,05\%, cakupan ASI Eksklusif 11,54\%, vitamin A untuk umur 6-12 bulan 90,89\% (Dinkes Kota, 2011) sedangkan menurut WHO tahun 2003, setelah usia 6 bulan, bayi sangat membutuhkan makanan tambahan untuk tumbuh dan menjadi aktif. ASI saja tidak cukup untuk memenuhi kebutuhan nutrisinya. Dengan demikian, makanan tambahan diberikan untuk mengisi kesenjangan antara kebutuhan nutrisi total pada anak dan jumlah yang didapatkan dari ASI (Dinkes, 2011).

Salah satu upaya yang ditempuh oleh pemerintah adalah upaya perbaikan gizi yang bertujuan untuk meningkatkan status gizi masyarakat yang diprioritaskan kepada kelompok masyarakat resiko tinggi yaitu golongan bayi, balita, usia sekolah, remaja, ibu hamil, dan menyusui serta usia lanjut. Pemberian ASI dapat mempercepat penurunan angka kematian bayi dan sekaligus meningkatkan status gizi balita yang pada akhirnya akan meningkatkan status gizi masyarakat menuju tercapainya kualitas sumber daya manusia yang memadai (Azwar, 2006).

Data Provinsi Aceh tahun 2011 menjelaskan bahwa cakupan pemberian makanan pendamping ASI (MP-ASI) pada usia 6-23 bulan merupakan suplemen tambahan untuk bayi usia 6-23 bulan, yang utama tetap ASI. Sehingga diharapkan jumlah dan frekuensi ASI yang diberikan tidak boleh berkurang hanya karena MP-ASI. Memberikan MP-ASI tidak sekedar memberikan makan, tetapi juga memberikan nutrisi dan kebiasaan kepada anak. Selain itu, MP-ASI juga mensinergikan kemampuan mengunyah, menelan menjadi optimal (Dinkes, 2011).

Adapun hasil pendataan di wilayah kerja Puskesmas Batoh Kota Banda Aceh pada bulan Oktober 2017 - Februari 2018, bayi yang berusia 7-12 bulan berjumlah 242 jiwa dari 9 desa dan 10 posyandu. Desa panteriek 31 jiwa, desa lueng bata 29 jiwa, desa lampaloh 7 jiwa, 
desa lamdom 19 jiwa, desa cot mesjid 20 jiwa, desa lembah hijau 20 jiwa, desa sukadamai 21 jiwa, desa lamseupeung 23 jiwa, desa blang cut 22 jiwa, desa batoh 50 jiwa. Bayi yang mendapatkan ASI Eksklusif 6 bulan yaitu 22 orang (40\%), bayi yang mendapatkan MP-ASI setelah usia 6 bulan sebanyak 33 orang (60\%). Selain itu berdasarkan dari hasil wawancara pada 12 orang ibu yang mempunyai bayi usia 7-12 bulan tentang pemberian MP-ASI dan jenis makanan yang diberikan didapatkan hasil bahwa ibu yang memberikan MP-ASI sebelum usia 6 bulan sebanyak 7 orang dan yang memberikan MP-ASI setelah 6 bulan sebanyak 5 orang (Data Laporan Puskesmas Batoh, 2017).

\section{METODE PENELITIAN}

Penelitian ini merupakan penelitian analitik dengan desain penelitian cross sectional. Penelitian ini dilakukan di Wilayah Kerja Puskesmas Batoh Banda Aceh pada tanggal 20-26 Februari 2018 terhadap ibu-ibu yang memiliki bayi usia 7-12 bulan. Populasi dalam penelitian ini adalah seluruh ibu yang mempunyai bayi usia 7-12 bulan yang berjumlah 242 orang yang tinggal di wilayah Kerja Puskesmas Batoh Banda Aceh tahun 2018. Penarikan sampel dalam penelitian ini adalah stratified random sampling yaitu penarikan sampel secara acak berlapis dengan teknik pengambilan sampel secara proporsional(stratified propotionate random sampling).

\section{HASIL DAN PEMBAHASAN}

Berdasarkan penelitian yang dilaksanakan pada tanggal 20-26 Februari 2018yaitu dengan jumlah responden 71 orang, mayoritas ibu tidak tepat dalam memberikan MP-ASI pada bayinya yaitu sebanyak 47 responden (66.2\%), sementara hanya 24 (33.8\%) ibu yang tepat dalam memberikan MP-ASI kepada bayinya.

Analisis bivariat menggunakan uji chi-square yang bertujuan untuk mengetahui hubungan variabel pengetahuan dan pekerjaan ibu denganpemberian MP-ASI. Hasil analisis bivariat tersebut disajikan pada tabel 1 sebagai berikut: 
Tabel 1. Hasil Analisis Bivariat Hubungan Pengetahuan dan Pekerjaan Ibu dengan Pemberian MP-ASI di Wilayah Kerja Puskesmas Batoh Banda Aceh tahun 2018

\begin{tabular}{|c|c|c|c|c|c|c|c|}
\hline \multirow[t]{2}{*}{ Variabel Independen } & \multicolumn{4}{|c|}{ Pemberian MP-ASI } & \multicolumn{2}{|c|}{ Total } & \multirow{2}{*}{$\begin{array}{c}\text { P- } \\
\text { Value }\end{array}$} \\
\hline & $\begin{array}{l}\text { Tidak } \\
\text { tepat }\end{array}$ & $\%$ & Tepat & $\%$ & $\mathbf{f}$ & $\%$ & \\
\hline \multicolumn{8}{|l|}{ Pengetahuan } \\
\hline 1. Kurang & 27 & 81.8 & 6 & 18.2 & 33 & 100 & \\
\hline 2. Cukup & 7 & 63.6 & 4 & 36.4 & 11 & 100 & 0.023 \\
\hline 3. Baik & 13 & 48.1 & 14 & 51.9 & 27 & 100 & \\
\hline \multicolumn{8}{|l|}{ Pekerjaan } \\
\hline 1. Tidak Bekerja & 5 & 15 & 35.7 & 64.3 & 14 & 100 & \\
\hline 2. Bekerja & 42 & 9 & 73.7 & 26.3 & 57 & 100 & 0.011 \\
\hline
\end{tabular}

\section{Hubungan Pengetahuan dengan Pemberian MP-ASI}

Dari hasil uji statistik dengan menggunakan chi-square menunjukkan perbedaan persentase tersebut bermakna yaitu dengan nilai $\mathrm{P}=0.019$ yaitu ada hubungan bermakna antara pengetahuan dengan pemberian MP-ASI di Wilayah Kerja Puskesmas Batoh Banda Aceh tahun 2018. Hasil analisis hubungan diperoleh bahwa dari 71 responden, pemberian MP-ASI secara tepat lebih besar dijumpai pada ibu yang berpengetahuan baik yaitu $51.9 \%$ dibandingkan dengan ibu yang berpengetahuan kurang yaitu $18.2 \%$ dan ibu yang berpengetahuan cukup $36.4 \%$.

Mutia (2010) meneliti tentang hubungan pengetahuan dan sikap ibu dengan Pemberian MP-ASI di Kelurahan SelayangKecamatan Medan Selayang, memperoleh hasil yang sama yaitu terdapat hubungan yang signifikan antara pengetahuan dengan pemberian MP-ASI dengan nilai $\mathrm{P}=0,023$. Sementara Hasil yang berbeda ditemukan dari hasil penelitian yang dilakukan Surinah (2009) tentang hubungan pekerjaan dengan pemberian MP-ASI yang menunjukkan hasil tidak terdapat hubungan pekerjaan dengan pemberian MP-ASI pada bayi.

Hasil survei menunjukkan bahwa salah satu penyebab terjadinya gangguan tumbuh kembang bayi dan anak usia 6 sampai 24 bulan di Indonesia adalah rendahnya mutu MPASI (makanan pendamping ASI) dan ketidak sesuaian pola asuh yang diberikan sehingga beberapa zat gizi tidak dapat mencukupi kebutuhan energi dan zat mikro terutama zat besi (Fe) dan Seng (Zn). Pemberian makanan adalah salah satu faktor yang mempengaruhi status gizi bayi. Pemberian makanan yang kurang tepat dapat menyebabkan terjadinya kekurangan gizi dan pemberian yang berlebihan akan terjadi 
kegemukan. Pada usia 6 bulan, secara fisiologis bayi telah siap menerima makanan tambahan, karena secara keseluruhan fungsi saluran cerna sudah berkembang. Selain itu, pada usia tersebut air susu ibu sudah tidak lagi mencukupi kebutuhan bayi untuk tumbuh kembangnya, sehingga pemberian makanan pendamping air susu ibu (MP-ASI) sangat diperlukan (Saleh, 2011).

Pemberian makanan selain ASI yang terlalu dini dapat mengakibatkan diarekarena kebersihan yang kurang. Produksi ASI pun berkurang karena anak sudahkenyang dan jarang menyusu. Selain itu menimbulkan alergi di kemudian hari karenausus bayi masih mudah dilalui protein asing. Terlalu lambat memberikan makananpendamping juga tidak baik karena ASI saja hanya bisa memenuhi kebutuhan bayisampai 6 bulan. Sehingga pemberian MP ASI lebih dari itu kemungkinan bayi akanmengalami malnutrisi (Soetjiningsih, 2011).

Hal ini pun sejalan dengan pendapat Notoadmodjo (2005) yang mengungkapkan bahwa prilaku yang didasari oleh pengetahuan akan lebih langgeng dari pada prilaku yang tidak didasari pengetahuan. Pengetahuan ibu tentang ASI pemberian MP-ASI dapat mempengaruhi ibu sehingga dalam memberikan MP-ASI menjadi tepat. Semakin baik pengetahuan ibu tentang manfaat MP-ASI, maka seorang ibu akan memberikan MP-ASI tepat sesuai dengan usia bayi.

Dari hasil penelitian juga menunjukkan bahwa pada ibu yang telah memiliki pengetahuan baik tentang MP-ASI masih terdapat yang tidak memberikan secara tepat, yaitu 13 responden $(48.1 \%)$.

Hal ini Sejalan dengan pendapat Roesli (2006), seiring dengan perkembangan zaman, terjadi pula peningkatan ilmu pengetahuan dan teknologi yang demikian pesat. Selain itu, Roesli juga mengungkapkan bahwa fenomena tidak tepatnya pemberian MPASI disebabkan oleh beberapa faktor diantaranya pengetahuan ibu yang kurang memadai tentang MP-ASI, beredarnya mitos yang kurang baik, serta kesibukkan ibu bekerja, merupakan alasan yang diungkapkan oleh ibu yang tidak tepat memberikan MP-ASI. Hal ini terutama tercermin dari pengetahuan ibu tentang jenis bahan dasar untuk pemberian MP-ASI, dimana pada umumnya ibu tidak mengetahui bahwa kandungan pemberian MPASI didasarkan pada usia bayi (Roesli, 2006).

Pengetahuan ibu dapat dipengaruhi oleh pengetahuan dan informasi yang didapat oleh ibu tentang MP-ASI. Pengetahuan atau kognitif merupakan hal yang sangat penting 
dalam membentuk tindakan seseorang, salah satunya kurang memadainya pengetahuan ibu tentang MP-ASI yang menjadikan tidak tepatnya pemberian MP-ASI(Hermina, 2011).

Asumsi peneliti, salah satu kondisi yang menyebabkan tidak tepatnya pemberian MP-ASI adalah masih kurangnya pengetahuan masyarakat dibidang kesehatan. Khususnya ibu-ibu yang mempunyai bayi. Melihat dari hasil penelitian, maka perlu dilakukan usaha untuk meningkatkan pengetahuan ibu tentang manfaat pemberian MPASI, dukungan Dokter, Bidan, Petugas kesehatan lainnya atau kerabat dekat sangat dibutuhkan terutama untuk ibu yang baru pertama pertama kali melahirkan dalam pemberian MP-ASI. Ibu yang pertama kali melahirkan belum memiliki pengetahuan yang baik ditambah lagi hal semakin dipersulit apabila ibu yang memiliki pendidikan rendah sehingga terhadap pemberian MP-ASI belum berpengalaman dibanding dengan ibu yang sudah memiliki anak sebelumnya.

\section{Hubungan Pekerjaan dengan Pemberian MP-ASI}

Dari hasil uji statistik dengan menggunakan chi-square menunjukkan perbedaan persentase tersebut bermakna yaitu dengan nilai $\mathrm{P}=0.011$ yaitu ada hubungan bermakna antara pekerjaan dengan pemberian MP-ASI di Wilayah Kerja Puskesmas Batoh Tahun 2018. Hasil analisis hubungan dapat dilihatbahwa dari 71 responden, pemberian MP-ASI secara tepat lebih besar dijumpai pada ibu yang tidak bekerja 64.3\% dibandingkan dengan ibu yang bekerja yaitu $26.3 \%$.

Hasil penelitian yang sama tentang pola pemberian makanan pendamping ASI berdasarkan tingkat konsumsi energi di wilayah Puskesmas Gedongtengen Yogyakarta menunjukkan bahwa, terdapat hubungan antara pola pemberian MP-ASI dengan pekerjaan ibu, hal ini dapat disebabkan oleh faktor pendidikan formal ibu dimana tingkat pendidikan formal berhubungan dengan pekerjaan ibu, yang ikut menentukan mudah tidaknya ibu menyerap dan memahami informasi gizi yang diperoleh.

Bekerja umumnya merupakan kegiatan yang menyita waktu sehingga bagi ibu-ibu yang bekerja akan mempunyai pengaruh terhadap kehidupan keluarga. Semakin banyak waktu yang tersita untuk melakukan pekerjaan maka semakin besar kesempatan untuk memberikan makanan pendamping ASI (Soekirman, 2010). 
Banyak ibu-ibu dengan anak 0-24 bulan bekerja mencari nafkah baik untuk kepentingan sendiri maupun keluarga, faktor bekerja saja nampaknya belum berperan sebagai penyebab timbulnya masalah kurang gizi, tetapi kondisi kerja lebih menonjol sebagai faktor yang mempengaruhi dalam pemberian makanan, gizi dan perawatan anak. Sebagian besar responden pada penelitian ini adalah ibu yang bekerja di luar rumah (56.3\%), sehingga ibu-ibu yang bekerja diluar rumah biasanya tidak memiliki pola asuh yang lebih baik terhadap tumbuh kembang balita daripada ibu dengan pekerjaan didalam rumah atau pekerjaan lain, dengan pola asuh yang baik maka ibu dapat melihat tumbuh kembang anak lebih baik, ibu lebih fokus dalam merawat dan mengasuh anak.

Depkes (2004) menyatakan dari hasil survei menunjukkan bahwa penyebab terjadinya gangguan tumbuh kembang bayi dan anak usia 6 sampai 24 bulan di Indonesia adalah rendahnya mutu MP-ASI dan ketidak sesuaian pola asuh yang diberikan sehingga beberapa zat gizi tidak dapat mencukupi kebutuhan energi dan zat mikro. Menurut UNICEF (1999) dalam Soekirman secara mendasar ada dua faktor yang mempengaruhi status gizi dan pertumbuhan bayi, yaitu intake gizi dan adanya penyakit infeksi. Kedua faktor ini mempunyai hubungan secara sinergis dimana zat gizi yang kurang dapat menyebabkan daya tahan tubuh rendah sehingga mudah terkena infeksi, sebaliknya infeksi penyakit dapat menyebabkan kekurangan gizi. Namun demikian pendapat Soekirman bahwa faktor-faktor yang mempengaruhi status gizi anak balita selain konsumsi makanan dan penyakit infeksi, juga dapat dipengaruhi oleh faktor genetik atau keturunan. Meskipun anak balita mempunyai pola makan dengan tingkat konsumsi energi yang baik, tapi bila anak balita tersebut mempunyai faktor genetik atau keturunan kurus, maka status gizinya juga tidak dapat lebih baik (Muchtadi, 2008).

Asumsi peneliti, juga menyatakan bahwa sosial ekonomi keluarga secara tidak langsung dapat mempengaruhi ketersediaan pangan dalam keluarga. Adanya ketersediaan pangan dalam keluarga mempengaruhi pola konsumsi yang selanjutnya mempengaruhi pola konsumsi yang selanjutnya berpengaruh terhadap intake gizi keluarga (Soeharjo, 2005).

Asumsi peneliti, faktor penyebab masalah yaitu terdapat banyak kendala yang dihadapi para ibu yang bekerja di luar rumah dalam memberikan MP-ASI kepada anaknya, terutama kendala seperti ibu tidak memiliki kesempatan banyak untuk mengasuh anaknya. Hal ini seharusnya dapat ditanggulangi dengan cara melakukan 
penyuluhan, baik melalui petugas kesehatan maupun mass media bahkan langsung kepada ibu-ibu. Faktor kurangnya petugas kesehatan sehingga masyarakat kurang mendapatkan penerangan/dorongan tentang cara pemberian MP-ASI. Penerangan yang salah justru datangnya dari petugas kesehatan itu sendiri yang jarang menjelaskan cara yang tepat dalam pemberianMP-ASI pada bayi.

\section{KESIMPULAN}

Terdapat hubungan yang bermakna antara pengetahuan ibu dengan pemberian MP-ASI, dan diperoleh nilai $\mathrm{P}=0.023(\mathrm{P}<0.05)$ dan terdapat hubungan yang bermakna antara pekerjaan ibu dengan pemberian MP-ASI dengan nilai $\mathrm{P}=0.011(\mathrm{P}<0.05)$.

\section{SARAN}

1. Kepada ibu-ibu untuk hendaknya tetap menyadari akan pentingnya pemberian makanan bergizi pada anak dan selalu menkonsultasikan masalah gizi anak kepada petugas kesehatan di puskesmas ataupun posyandu selain itu partisipasi keluarga hendaknya lebih ditingkatkan, mengingatkan keluarga untuk tetap menjaga pola asuh yang benar bagi balita. Dan untuk ibu yang bekerja meluangkan waktunya untuk memperhatikan makanan yang diberikan kepada bayinya dengan tidak menyerahkan sepenuhnya kepada pengasuh.

2. Kepada pengambil kebijakan, untuk dapat menghilangkan pengaruh iklan susu formula sehingga program pemberian ASI Eksklusif dapat berjalan lancar agar generasi penerus bangsa menjadi cerdas.

3. Kepada tenaga kesehatan, hendaknya dapat mempertahankan dan meningkatkan kegiatankegiatan yang berhubungan dengan status gizi balita dan program MP-ASI seperti memberikan penyuluhan tentang cara pemberian MP-ASI yang baik dan benar dan memperbanyak materi-materi tentang gizi, selalu memberikan motivasi kepada ibu-ibu agar tetap menjaga pola asuh dalam keluarga, mempertahankan peran serta kader posyandu yang langsung berhubungan dengan masyarakat agar tercapai status gizi anak yang lebih baik, pemberian MP-ASI kepada balita gizi buruk dan gizi kurang serta memberikan rujukan bagi balita gizi buruk ke rumah sakit untuk pemeriksaan lebih lanjut.

4. Kepada peneliti lain agar hasil penelitian ini diharapkan dapat memberikan masukan untuk penelitian lebih lanjut khususnya dalam hal ini ilmu kebidanan tentang makanan pendamping ASI. 


\section{DAFTAR PUSTAKA}

Asiyah, S. (2010). Karakteristik Bayi Berat Lahir Rendah (BBLR) Sampai Tri Wulan II. Tahun 2009. Kediri.

Budiarto, (2001). Biostatistik Untuk Kedokteran Dan Kesehatan Masyarakat. EGC, Jakarta.

Chapman DJ. Peres-Escamilla R: Identification of risk factors for delayed onset of laction. J Am Diet Assoc 99:450-454. 1999

Dewey K. (2001). Maternal and fetal stress are assocated with impaired lactogenesis in human, journal of nutrition.

(2003). Risk Factors For Suboptimal Infant Breastfeeding Behavior, Delayed Onset of Lactation, and Excess Neonatal Weight Loss.

----------(2013). Risk Factors For Suboptimal Infant Breastfeeding Behavior, Delayed Onset of Lactation, and Excess Neonatal Weight Loss

Edmond KM, Zandoh C, Quigley MA, Amenga- Etego S, Owusu-Agyei S, Kirkwood BR. Delayed Breastfeeding initiation increases risk of neonatal mortality. Pediatriss 2006.

Faizatun, N. (2012). Hubungan antara status pekerjaan, pendidikan, tingkat pengetahuan ibu, serta dukungan bidan terhadap pemberian asi eksklusifDi wilayah kerja puskesmas gribig. Didapat dari http://fk.ub.ac.id/artikel/id/filedownload/kebidanan/Majalah\%20FAIZATUN\%20NIK MA.pdf.

Graimes. N. (2008). Whole Foods Kitchen. World Publication Group. Didapat dari http://www.ebay.com/ctg/Whole-Foods-Kitchen-Nicola-Graimes-2008-Hardcover/116900927. diunduh tanggal 12 Juni 2013.

Grajeda R. Perez-Escamilla R: Stress during labor and delivery is associated wit delayed onset of lactation amongurban Guatemalan women. J Nurt 132: 3055-3060. 2002

Hartini, E.E. (2011). Pengaruh Onset Laktasi Terhadap Praktik Pemberian ASI Pada Neonatus. Palangkaraya

Hruschka, D. J. Sellen, D. W. Stein, A. D. dan Martorell, R. (2003) Delayed Onset Of Lactation and Risk of Ending Full Breast - Feeding Early In Rural Guatemala. J. Nutr. 1332592-99

Hildebrandt H: Maternal perception of lactogenesis time and clinical report. J Hum Lac 15: 317-323. 1999

Khassawneh, M. Khader, Y. Amatin, Z. dan Alkafajei, A. (2006), Knowledge, Attitude and Practice of Breasfeeding in the North of Jordan : A Crossectional study. Int Breasfeeding.

Krisnatuti. D. (2000). Menyiapkan Makanan Pendamping ASI. Jakarta: Niaga Swadaya.

Nurliawaty, (2010), faktor- faktor Yang Berhubungan Dengan Produksi ASI Pada Ibu Post SC Tasikmalaya 2010

Notoadmojo S., (2005), Metodologi penelitian Kesehatan, Rineka Cipta, jakarta. (2010). Ilmu Kesehatan Masyarakat. Rineka Cipta, Jakarta

Riskesdas, (2010). Riset Kesehatan Dasar 2010. Jakarta: Departemen kesehatan Republik Indonesia 
Roesli, U. (2008). Inisiasi menyusui Dini, Pustaka Bunda, Jakarta.

Rosi. N. (2010). Kajian Stunting pada Anak Balita Ditinjau dari Pemberian ASI Eksklusif, MP-ASI, Status Imunisasi dan Karakteristik Keluarga di Kota Banda Aceh Tahun 2010, 36-72. In Nasuwakes.

Sistiarani, C. (2008). Faktor Martenal Dan Kualitas Pelayanan Antenatal yang Beresiko Terhadap Kejadian Berat Badan Lahir Rendah (BBLR) di RSUD Banyumas.

UNICEF, (2007). Initiation of Breastfeeding. By Breast Crawl. UNICEF.

WHO. (2003). Global Strategy for Infant and Young Child Feeding. Didapat dari http://www.who.int/nutrition/topics/global_strategy/en/. diunduh tanggal 14 Juni 2013.

Wulandari, (2012).Tingkat Pengetahuan Ibu Nifas Tentang Bendungan ASI di RB Annur Sumber Surakarta,2012. 